\title{
STRATEGI PENANGGULANGAN RESIKO BENCANA PADA BADAN PENANGGULANGAN BENCANA DAERAH KABUPATEN BUTON
}

\author{
Muh. Askal Basir ${ }^{1}$ \\ Fakultas Ilmu Sosial dan Ilmu Politik Universitas Muhammadiyah Buton \\ Email: askal16basir@gmail.com
}

\begin{abstract}
ABSTRAK
Tujuan penelitian ini adalah Bagaimana Strategi Penanggulangan Resiko Bencana Pada Badan Penanggulangan Bencana Daerah Kabupaten Buton dan Faktor-faktor yang mempengaruhi Strategi Penanggulangan Resiko Bencana Pada Badan Penanggulangan Bencana Daerah Kabupaten Buton. Teknik analisis yang digunakan dalam penelitian ini adalah Analisis SWOT menggambarkan secara jelas bagaimana peluang dan ancaman eksternal yang dihadapi organisasi/perusahaan dapat disesuaikan dengan kekuatan dan kelemahan yang dimilikinya. Hasil Penelitian ini adalah Startegi BPBD dalam Penanggulangan Bencana Kabupaten Buton dapat dapat dilakukan dengan menerapkan SO (strengths-opportunity), Meningkatkan kualitas dan pelayanan aparatur, Meningkatkan kerja sama tim. Dan menerapkan ST (strengths-Treats), Memanfaatkan anggaran yang diberikan Pemerintah Pusat, Meningkatkan kerjasama dengan antar daerah. Menerapkan WO (weakness-opportunity), Menambah jumlah pegawai, Meningkatkan koordinasi pelaksanaan penanggulangan bencana, Meningkatkan komunikasi yang baik dengan Pemerintah Pusat. Dan juga menerapkan WT (weakness-treats), Mendorong berkembangannya tangguna jawab aparatur BPBD, Meningkatkan jumlah Tim Reaksi Cepat, Meningkatkan motivasi terhadap pegawai
\end{abstract}

Kata Kunci: Strategi, Resiko Bencana , Penanggulangan

\section{DISASTER RISK MANAGEMENT STRATEGY IN BUTON DISTRICT DISASTER MANAGEMENT AGENCY}

\begin{abstract}
The purpose of this study is how the Disaster Risk Management Strategy in the Disaster Management Agency of the District of Buton and the factors that influence the Disaster Risk Management Strategy in the Disaster Management Agency of the Districts Buton. The analytical technique used in this study is the SWOT analysis that clearly describes how the opportunities and external threats facing the organization / company can be adjusted to the strengths and weaknesses that it has. The results of this study are that the BPBD strategy in the disaster management of the regency of Buton can be done by applying SO (strengths-opportunity), improving the quality and service of the device, increasing teamwork. And applying ST (strong points), using the budget provided by the central government, increasing cooperation between the regions. Implementation of WO (weakness-opportunity), Increase in the number of employees, Increased coordination of the implementation of disaster management, Improvement of good communication with the Central Government. And also applying WT (treatment of weakness), promoting the development of the response capacity of the BPBD device, increasing the number of rapid reaction teams, increasing employee motivation
\end{abstract}

Keywords: Strategy, Disaster Risk, Mitigation 
Korespondensi: Muh. Askal Basir, ST., M.Si. Universitas Muhammadiyah Buton. Alamat: Jl. Betoambari No. 36 Kota Baubau Sulawesi Tenggara kode Pos 93717. No. HP, WhatsApp: 085256750111 Email: askal16basir@gmail.com

\section{PENDAHULUAN}

Bencana alam selama ini selalu dipandang sebagai forcemajore yaitu sesuatu hal yang berada di luar control manusia. oleh karena itu, untuk meminimalisir terjadinya korban akibat bencana diperlukan kesadaran dan kesiapan masyarakat dalam menghadapi bencana. Kesadaran dan kesiapan menghadapi bencana ini idealnya sudah dimiliki oleh masyarakat melalui kearifan lokal daerah setempat, karena mengingat wilayah Indonesia merupakan daerah yang mempuyai risiko terhadap bencana.

Secara geografis, geologis, hidrologis, dan sosio-demografis, Indonesia merupakan wilayah yang mempunyai risiko terhadap bencana. Secara geografis Indonesia merupakan negara kepulauan yang terletak pada pertemuan empat lempeng tektonik yaitu lempeng Benua Asia dan Benua Australia serta lempeng Samudera Hindia dan Samudera Pasifik. Terdapat 130 gunung merapi aktif dan terdapat lebih dari 5.000 sungai besar dan kecil yang 30\% di antaranya melewati kawasan padat penduduk dan berpotensi terjadinya banjir, banjir bandang dan tanah longsor pada musim hujan (Depkes RI, 2007).

Menurut Bakornas Penanggulangan Bencana (2007), risiko bencana adalah interaksi antara tingkat kerentanan daerah dengan ancaman bahaya (hazards). Ancaman bahaya khususnya bahaya alam bersifat tetap karena bagian dari dinamika proses alami pembangunan atau pembentukan roman muka bumi baik dari tenaga internal maupun eksternal, sedangkan tingkat kerentanan (vulnerability) daerah dapat dikurang dengan melakukan mitigasi (tindakan preventif), serta kemampuan/ketahanan dalam menghadapi ancaman (disaster resilience) tersebut semakin meningkat sehingga dapat meminimalisir dampak akibat bencana

Penanggulangan bencana (PB) sebagai rangkaian kegiatan baik sebelum maupun saat dan sesudah terjadi bencana dilakukan untuk mencegah, mengurangi, menghindari dan memulihkan diri dari dampak yang ditimbulkan oleh bencana. Secara umum kegiatan-kegiatan yang dilakukan dalam penanggulangan bencana adalah sebagai berikut: pencegahan, pengurangan dampak bahaya, kesiapsiagaan, tanggap darurat, pemulihan (rehabilitasi dan rekonstruksi), dan pembangunan berkelanjutan yang mengurangi risiko bencana (UNDP Indonesia, 2007:23)

Demi pengurangan risiko bencana untuk mewujudkan ketangguhan masyarakat, mitigasi dan kesiapsiagaan merupakan salah satu bagian vital, dan peningkatan dalam kedua hal ini merupakan salah satu agenda strategis. Dalam rangka mewujudkan agenda pengembangan sinergi dalam pengurangan risiko bencana kita diingatkan pada lima hal yang harus diantisipasi. Lima hal tersebut yaitu: 1) pengetahuan dan sikap terhadap resiko bencana; 2) kebijakan dan panduan; 3) rencana untuk keadaan darurat bencana; 4) sistim peringatan bencana; 5) kemampuan untuk memobilisasi sumber daya (LIPIUNESCO/ISD: 2006). 
Salah satu bencana yang sering terjadi di Kabupaten Buton adalah Abrasi Pantia, dimana abrasi merupakan suatu peristiwa mundurnya garis pantai (Triatmodjo, 1999) pada wilayah pesisir pantai yang rentan terhadap aktivitas yang terjadi di daratan maupun di laut. Aktivitas seperti penebangan hutan mangrove, penambangan pasir, serta fenomena tingginya gelombang, dan pasang surut air laut menimbulkan dampak terjadinya abrasi atau erosi pantai. Pengikisan yang terjadi pada daratan wilayah pantai menyebabkan angkutan sedimen berpindah dari tempat asalnya dan menyusuri arah gelombang datang, sehingga mempengaruhi perubahan pada garis pantai

Tujuan Penelitian ini adalahdalam penelitian ini adalah

1. Untuk Mengetahui Strategi Penanggulangan Resiko Bencana Pada Badan Penanggulangan Bencana Daerah Kabupaten Buton.

2. Untuk Mengetahui Faktor-faktor yang mempengaruhi Strategi Penanggulangan Resiko Bencana Pada Badan Penanggulangan Bencana Daerah Kabupaten Buton

\section{METODE PENELITIAN}

Jenis penelitian yang digunakan dalam penelitian ini adalah penelitian deskriptif dengan pendekatan kualitatif. Dalam pendekatan kualitatif yang terpenting adalah bagaimana menentukan informan kunci yang sarat informasi sesuai dengan fokus penelitian Moleong (2011). Metode kualitatif dapat digunakan untuk mengungkap dan memahami sesuatu dibalik fenomena yang sedikitpun belum diketahui.
Menurut Sugiyono (2005) "populasi adalah wilayah generalisasi yang terdiri atas obyek/subyek yang mempunyai kualitas dan karakteristik tertentu yang ditetapkan oleh peneliti untuk dipelajari dan kemudian ditarik kesimpulannya." Jadi populasi penelitian ini adalah Seluruh BPBD Kabupaten Buton yang berjumlah 21 orang.

Menurut Sugiyono (2005 : 91), "sampel adalah bagian dari jumlah dan karakteristik yang dimiliki oleh populasi tersebut". Adapun sampel dari penelitian ini adalah Kepala BPBD, Kepala Bidang Penaggulangan Kedaruratan dan Logistik, Kepala Bidang Pencegahan dan Kesiapsiagaan serta Staff BPBD.

Analisis ini didasarkan pada logika yang dapat memaksimalkan kekuatan (Strength) dan peluang (Opportunity). Namun secara bersamaan dapat meminimalkan kelemahan (Weakness) dan ancaman (Threat), yang diharapkan mampu untuk menyeimbangkan antara kondisi internal yaitu: kekuatan dan kelemahan dengan kondisi ekternal yaitu peluang dan ancaman yang ada, kemudian diimplementasikan dalam matriks SWOT, untuk mendapatkan beberapa strategi terbaik (the best strategy)

Matrik SWOT merupakan cara sistematik untuk mengidentifikasi keempat faktor yang tercakup dalam analisis yang menggambarkan kecocokan paling baik diantaranya. Analisis ini didasarkan pada asumsi bahwa suatu strategi akan memaksimalkan kekuatan dan peluang, serta meminimalkan kelemahan dan ancaman. Matrik SWOT digunakan untuk mengembangkan empat tipe alternatif strategi yaitu SO (strengths- 
opportunities), strategi WO (weaknessesopportunities), strategi ST (strengths-threats), dan strategi WT (weaknesses- threats). Terdapat empat tahapan dalam membentuk matrik SWOT yaitu:

a. Mencocokan kekuatan internal dengan peluang eksternal dan mencatat resultan strategi SO.

b. Mencocokan kelamahan internal dengan peluang eksternal dan mencatat resultan strategi WO

c. Mencocokan kekuatan internal dengan ancaman eksternal dan mencatat resultan strategi ST.

d. Mencocokan kelemahan internal dengan ancaman dan mencatat resultan strategi WT. Analisis ini dapat menghasilkan empat kemungkinan alternatif strategis (Rangkuti, 2009:19-31) seperti tergambar pada Matrik SWOT berikut ini:

\begin{tabular}{|c|c|c|}
\hline IFAS & \begin{tabular}{l}
\multicolumn{2}{c}{ STRENGTHS } \\
Tentukan \\
Faktor-faktor \\
kekuatan Internal
\end{tabular} & $\begin{array}{l}\text { WEAKNESSES } \\
\text { Tentukan } 4 \\
\text { Faktor-faktor } \\
\text { kelemahan } \\
\text { Internal }\end{array}$ \\
\hline OPPORTUNITIES & Strategi SO & Strategi $W O$ \\
\hline $\begin{array}{l}\text { Tentukan } 4 \\
\text { Faktor-faktor } \\
\text { peluang } \\
\text { Eksternal }\end{array}$ & $\begin{array}{l}\text { Ciptakan strategi } \\
\text { yang } \\
\text { menggunakan } \\
\text { kekuatan utk } \\
\text { memanfaatkan } \\
\text { peluang }\end{array}$ & $\begin{array}{l}\text { Ciptakan } \\
\text { strategi yang } \\
\text { meminimalkan } \\
\text { kelemahan utk } \\
\text { memanfaatkan } \\
\text { peluang }\end{array}$ \\
\hline TREATHS & Strategi $S T$ & Strategi WT \\
\hline $\begin{array}{l}\text { Tentukan } 4 \\
\text { Faktor ancaman } \\
\text { Ekternal }\end{array}$ & $\begin{array}{l}\text { Ciptakan strategi } \\
\text { yg menggunakan } \\
\text { kekuatan untuk } \\
\text { mengatasi } \\
\text { ancaman }\end{array}$ & $\begin{array}{l}\text { Ciptakan } \\
\text { strategi yg } \\
\text { meminimalkan } \\
\text { kelemahan dan } \\
\text { menghindari } \\
\text { ancaman }\end{array}$ \\
\hline
\end{tabular}

Gambar 1. Matrik SWOT

\section{HASIL DAN PEMBAHASAN}

Kinerja BPBD Kabupaten Buton dapat dilihat dengan keberhasilan dalam pelaksanaan tugas Kantor Badan Penanggulangan Bencana Daerah Kabupaten
Buton untuk mencapai visi dan misi yang telah ditetapkannya sangat dipengaruhi oleh lingkungan strategis sebagai penentu keberhasilan dalam kinerja BPBD Kabupaten Buton. Artinya, apabila kinerja BPBD Kabupaten Buton ini mencapai visi dan misinya dapat memberikan pelayanan yang baik untuk korban bencana maka kinerja BPBD Kabupaten Buton dianggap berhasil dalam menjalankan tugasnya. Sebaliknya, apabila masyarakat yang menjadi korban bencana tersebut menganggap kinerja BPBD Kabupaten Buton tidak efektif maka kinerja BPBD Kabupaten Buton tersebut dianggap gagal dalam menjalankan tugasnya.

Hal ini sesuai dengan teori kinerja yang dikemukakan oleh T.R.Mitchell ada lima hal yang menjadi ukuran kinerja, yakni :

a. Quality Of Work-Kualitas Hasil Kerja

b. Promptness - Ketetapan Waktu

Menyelesaikan Pekerjaan

c. Initiative -Prakarsa Dalam Menyelesaikan Pekerjaan

d. Capability - Kemampuan Dalam menyelesaikan Pekerjaan.

e. Communication-Kemampuan Membina Kerjasama Dengan Pihak lain

\section{a. Kualitas Hasil Kerja}

Adapun Kualitas Hasil kerja di Kantor Badan Penanggulangan Bencana Daerah Kabupaten Buton adalah memberikan perlindungan kepada masyarakat yang menjadi korban bencana dari ancaman bencana. Hal ini juga terdapat dalam Undang-undang No.24 Tahun 2007 Pasal 4 yang meyatakan bahwa Penanggulangan bencana bertujuan untuk 
memberikan perlindungan kepada masyarakat dari ancaman bencana. Maka berdasarkan hasil wawancara dan observasi oleh peneliti, maka dapat dijabarkan sebagai berikut :

Kepala Pelaksana Badan Penanggulangan Bencana Daerah Kabupaten Buton berharap terbentuknya BPBD Kabupaten Buton ini dapat menangani masalah bencana dengan Optimal. Dan memberikan perlindungan untuk korban bencana. Serta masyarakat yang dapat bekerjasama dengan BPBD Kabupaten Buton agar permasalahan yang terjadi dalam penanggulangan bencana dapat diselesaikan dengan mudah dan cepat.

Kualitas kinerja BPBD Kabupaten Buton sudah cukup baik dalam menangani bencana. Meskipun masih ada masalah-masalah yang ada di BPBD Kabupaten Buton tetapi BPBD Kabupaten Buton sudah berusaha untuk dapat menjalankan tugas dan fungsinya dengan baik.

\section{b. Ketepatan Waktu Menyelesaikan Pekerjaan}

Cepat dan tepatnya suatu pekerjaan juga didukung dengan adanya sarana dan prasarana yang memadai. Selain itu, agar cepat terselesaikannya suatu pekerjaan juga dengan disiplinnya pegawai. Pendidikan dan pelatihan para pegawai juga sangat mendukung dalam cepat selesainya suatu pekerjaan.

Adanya hambatan yang ada di BPBD Kabuapten Buton, seperti kurangnya sarana dan prasarana dan kurangnya anggaran untuk mendukung cepat selesainya suatu pekerjaan menyebabkan kurang tepat waktunya BPBD Kabupaten Buton dalam menjalankan tugas dan fungsinya.

\section{c. Inisiatif}

Usaha yang dilakukan BPBD Kabupaten Buton untuk mencapai kinerja yang diinginkan dengan sering mensosialisikan kepada masyarakat agar masyarakat mudah terlibat dalam penanganan bencana, seperti pembentukan posko bencana, informasi kerusakan, dan evakuasi.

inisiatif atau usaha BPBD Kabupaten Buton sudah cukup maksimal dalam menajalankan tugas dan fungsinya. Adanya usaha dari BPBD Kabupaten Buton yaitu tetap siaga apabila terjadi bencana dengan cuaca yang kurang baik tetapi BPBD Kabupaten Buton tetap menjalankan tugasnya.Dan adanya inisiatif BPBD Kabupaten Buton yang mensosialisasikan kepada masyarakat tentang tanggap darurat memudahkan masyarakat dalam menangani bencana yang terjadi. Mereka jadi sudah dapat mengantisipasi dan sudah mengetahui tempattempat yang aman apabila bencana terjadi.

\section{d. Kemampuan menyelesaikan pekerjaan}

Kinerja BPBD Kabupaten Buton sangat perlu didukung dengan adanya sarana dan prasarana yang lengkap dan canggih.Sehingga BPBD Kabupaten Butondapat menjalankan tugas dan fungsinya dengan baik. Dan apabila sarana dan prasarana yang memadai pihak BPBD Kabupaten Buton akan lebih cepat dalam menjalankan tugasnya. Selain sarana dan prasarana, koordinasi dengan pihak-pihak lain juga snagat membantu BPBD Kabupaten Buton dalam menangani masalah bencana. Adanya sumber daya manusia yang berkualiatas sesuai dengan keahliannya juga sangat membantu cepat terselesainya suatu pekerjaan dengan maksimal.

Pegawai BPBD Kabupaten Buton telah menjalankan tugas dengan cukup baik dan cepat 
tanggap dalam menangani masalah bencana.Tetapi karena kurangnya jumlah SDM, kurangnya koordinasi antar instansi pemerintah dan kurangnya sarana dan prasarana yang diberikan kepada BPBD Kabupaten Buton membuat kinerja BPBD Kabupaten Buton tidak dapat berjalan maksimal.

\section{e. Kemampuan membina kerjasama dengan pihak lain}

Dalam menjalankan tugas dan fungsinya sangat perlu mendapatkan dukungan dari pihak-pihak lain. Agar suatu pekerjaan dapat dijalani dengan maksimal. Dengan mampu menjalin kerjasama dengan pihak laindapat membantu BPBD Kabupaten Buton dalam mengatasi penanggulangan bencana. Komunikasi yang baik juga dapat mendukung dalam penanggulangan bencana ini, dimana kemampuan membina kerjasama dengan pihak lain sudah bagus. Banyak pihak-pihak lain yang memiliki kepedulian yang tinggi dalam penanggulangan bencana

Keberhasilan dalam pelaksanaan tugas Kantor Badan Penanggulangan Bencana Daerah (BPBD) Kabupaten Buton untuk mencapai Visi dan Misi yang telah ditetapkannya sangat dipengaruhi oleh lingkungan strategis sebagai faktor penentu keberhasilan dalam kinerja BPBD Kabupaten Buton. Untuk dapat mengidentifikasi faktor- faktor penentu keberhasilan maka terlebih dahulu perlu dianalisa sampai seberapa jauh misi Badan Penanggulangan Bencana Daerah Kabupaten Buton dipengaruhi oleh faktor intern dan ekstern organisasi. Dengan mengetahui pengaruh intern dan ekstern organisasi maka untuk dapat mencapai keberhasilan pelaksaan tugas perlu didorong dan ditumbuhkembangkan faktor organisasi yang memberi kekuatan dan peluang guna dimanfaatkan untuk pengembangan suatu organisasi. Sebaliknya faktor yang menjadi penghambat organisasi seperti kelemahan dan ancaman dapat diantisipasi dengan diatasi sejak dini agar tidak dapat berpengaruh negative terhadap upaya pencapaian tujuan organisasi. Indikator Kinerja menggunakan analisis SWOT untuk mengetahui bagaimana kekuatan,kelemahan,peluang dan ancaman dalam kinerja Badan Penanggulangan Bencana Daerah Kabupaten Buton dalam upaya penanggulangan bencana tersebut

Dari analisis internal dan eksternal SWOT tentang Kinerja BPBD Kabupaten Buton memperoleh strategi dalam menghadapi kendala yang ada di BPBD Kabupaten Buton, yaitu :

\section{1) STRATEGI SO}

a. Meningkatkan kualitas dan pelayanan aparatur agar dapat menangani masalah bencana secara maksimal.

b. Meningkatkan kerja sama tim dengan pihak pihak lain agar masalah yang dihadapi dalam penanggulangan bencana berjalan dengan mudah

\section{2) STRATEGI ST}

a. Memanfaatkan anggaran yang diberikan Pemerintah Pusat dengan menggunakan sebaik-baiknya.

b. Meningkatkan kerjasama dengan antar daerah agar penanggulangan dapat diatasi dengan cepat.

\section{3) STRATEGI WO}

a. Menambah jumlah pegawai agar penanganan bencana dapat diselesaikan dengan cepat. 
b. Meningkatkan koordinasi pelaksanaan penanggulangan bencana

c. Meningkatkan komunikasi yang baik dengan Pemerintah Pusat agar dapat selalu mendukung BPBD Kabupaten Butondalam mengatasi bencana.

\section{4) STRATEGI WT}

a. Mendorong berkembangannya tanggung jawab aparatur BPBD

b. Meningkatkan jumlah Tim Reaksi Cepat agar lebih dapat membantu dalam pennaganan bencana di lapangan.

Meningkatkan motivasi terhadap pegawai agar pegawai semangat dalam menjalankan tugas dan fungsinya.

\section{Tabel 2. Matriks Keberhasilan dengan SWOT}

\begin{tabular}{|c|c|c|}
\hline & Kekuatan (S) & Kelemahan \\
\hline Faktor Internal & 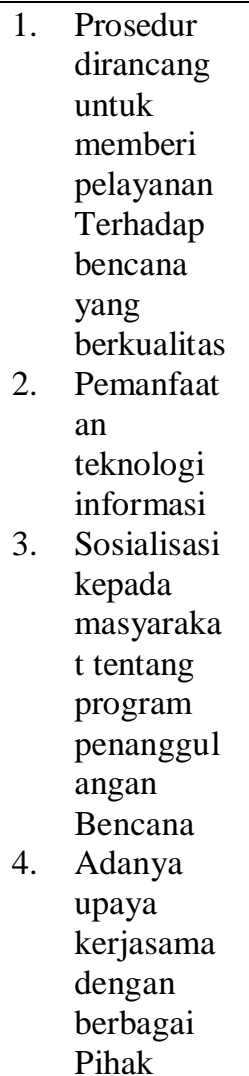 & 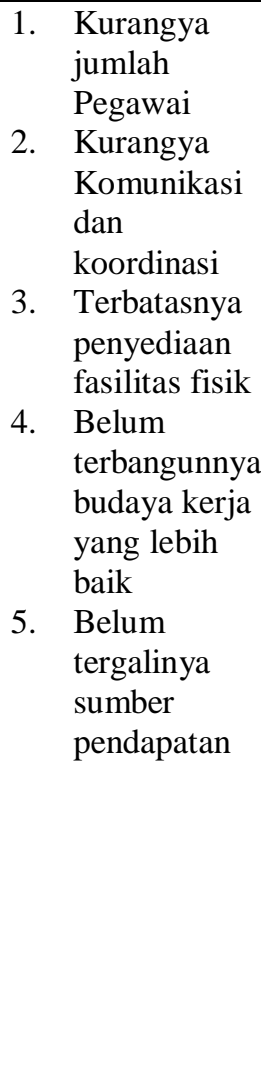 \\
\hline Peluang $(\mathrm{O})$ & Strategi (SO) & Strategi (WO) \\
\hline $\begin{array}{l}\text { 1. Mam } \\
\text { pu } \\
\text { mem }\end{array}$ & $\begin{array}{l}\text { 1. Meningkatk } \\
\text { an kualitas } \\
\text { dan }\end{array}$ & $\begin{array}{l}\text { 1. Menambah } \\
\text { jumlah } \\
\text { pegawai agar }\end{array}$ \\
\hline
\end{tabular}

\begin{tabular}{|c|c|c|}
\hline $\begin{array}{ll}\text { enuhi } \\
\text { harap } \\
\text { an } \\
\text { masy } \\
\text { araka } \\
\mathrm{t}\end{array}$ & $\begin{array}{l}\text { pelayanan } \\
\text { aparatur } \\
\text { agar dapat } \\
\text { menangani } \\
\text { masalah } \\
\text { bencana } \\
\text { secara } \\
\text { maksimal. } \\
\text { Meningkatk } \\
\text { an kerja } \\
\text { sama tim } \\
\text { dengan } \\
\text { pihak-pihak } \\
\text { lain agar } \\
\text { masalah } \\
\text { yang } \\
\text { dihadapi } \\
\text { dalam } \\
\text { penanggula } \\
\text { ngan } \\
\text { bencana } \\
\text { berjalan } \\
\text { dengan } \\
\text { mudah }\end{array}$ & $\begin{array}{l}\text { penanganan } \\
\text { bencana } \\
\text { dapat } \\
\text { diselesaikan } \\
\text { dengan cepat. } \\
\text { 2. } \text { Meningkatka } \\
\text { n koordinasi } \\
\text { pelaksanaan } \\
\text { penanggulan } \\
\text { gan bencana } \\
\text { Meningkatka } \\
\text { n komunikasi } \\
\text { yang baik } \\
\text { dengan } \\
\text { Pemerintah } \\
\text { Pusat agar } \\
\text { dapat selalu } \\
\text { mendukung } \\
\text { BPBD } \\
\text { Kabupaten } \\
\text { Buton dalam } \\
\text { mengatasi } \\
\text { bencana }\end{array}$ \\
\hline Ancaman (T) & Strategi (ST) & Strategi (WT) \\
\hline 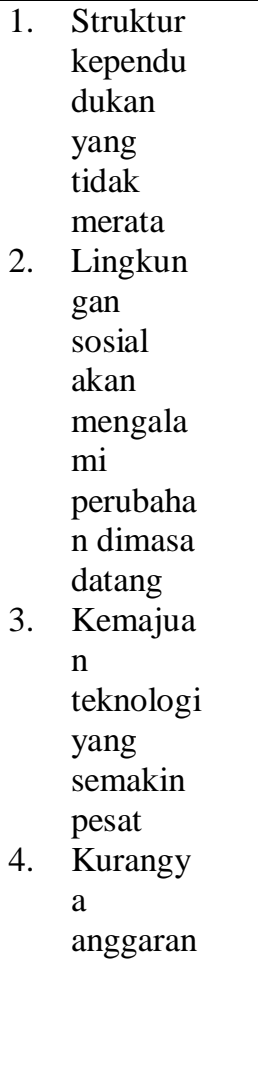 & $\begin{array}{l}\text { 1. Memanfaat } \\
\text { kan } \\
\text { anggaran } \\
\text { yang } \\
\text { diberikan } \\
\text { Pemerintah } \\
\text { Pusat } \\
\text { dengan } \\
\text { menggunak } \\
\text { an sebaik- } \\
\text { baiknya. } \\
\text { Meningkatk } \\
\text { an } \\
\text { kerjasama } \\
\text { dengan } \\
\text { antar } \\
\text { daerah agar } \\
\text { penanggula } \\
\text { ngan dapat } \\
\text { diatasi } \\
\text { dengan } \\
\text { cepat }\end{array}$ & 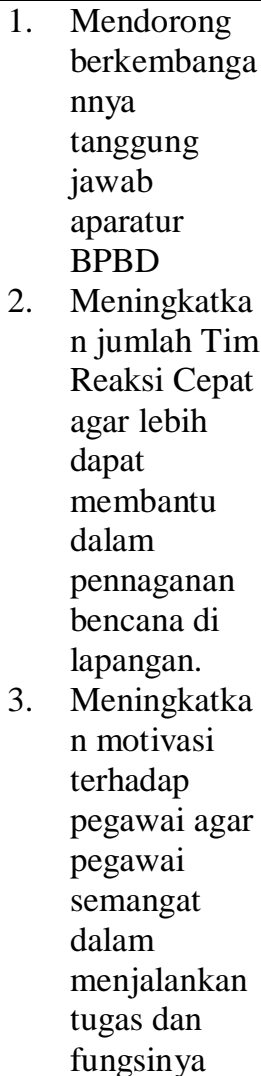 \\
\hline
\end{tabular}

\section{SIMPULAN}

Kesimpulan sebagai berikut adalah Startegi BPBD dalam Penanggulangan Bencana Kabupaten Buton dapat dilakukan dengan menerapkan SO 
(strengths-opportunity), Meningkatkan kualitas dan pelayanan aparatur, Meningkatkan kerja sama tim, Dan menerapkan ST (strengths-Treats), Memanfaatkan anggaran yang diberikan Pemerintah Pusat, Meningkatkan kerjasama dengan antar daerah. Menerapkan WO (weakness-opportunity), Menambah jumlah pegawai, Meningkatkan koordinasi pelaksanaan penanggulangan bencana, Meningkatkan komunikasi yang baik dengan Pemerintah Pusat. Dan juga menerapkan WT (weakness-treats), Mendorong berkembangannya tangguna jawab aparatur BPBD, Meningkatkan jumlah Tim Reaksi Cepat, Meningkatkan motivasi terhadap pegawai

\section{DAFTAR PUSTAKA}

Bakornas Penanggulangan Bencana. 2007. Pengenalan Karakteristik Bencana dan Upaya Mitigasinya di Indonesia. Direktorat Mitigasi Lahar BAKORNAS PB: Jakarta.

Depkes RI. 2007. Profil Kesehatan 2007. Departemen Kesehtan RI .

LIPI-UNESCO/ISDR. 2006. Kajian Kesiapsiagaan Masyarakat Dalam Mengantisipasi Bencana Gempa Bumi dan Tsunami. Jakarta.

Moleong, L.J. 2011. Metodologi Penelitian Kualitatif Edisi Revisi. Bandung: PT. Remaja Rosdakarya

Rangkuti, Freddy. 2009. Strategi Promosi yang Kreatif dan Analisis. Kasus. Integrated Marketing Communication. Jakarta : PT. Gramedia Pustaka Utama

Sugiyono, 2005, Metode Penelitian Administrasi, Alfabeta, Bandung.

Triatmodjo, B. 1999. Teknik Pantai. Beta Offset. Yogyakarta

UNDP Indonesia, 2007. Laporan Tahunan UNDP. Jakarta 